\title{
Assessing livelihood-ecosystem interdependencies and natural resource governance in a tribally controlled region of India's north-eastern middle Himalayas
}

\author{
Mark Everard $^{1}$ D . Gaurav Kataria ${ }^{2} \cdot$ Smita Kumar $^{2} \cdot$ Nishikant Gupta $^{1}$
}

Received: 24 January 2020 / Accepted: 12 August 2020 / Published online: 28 August 2020

(c) The Author(s) 2020

\begin{abstract}
Mountains host high biological and cultural diversity, generating ecosystem services beneficial over multiple geographical scales but suffering significant vulnerabilities. A case study in Lileng village (Arunachal Pradesh, Indian north-east Himalayas) explored linkages between a community with protected tribal rights and the forest and river ecosystems within which they are situated. Evidence was gathered through interviews and literature review about ecosystem service benefits, using the Rapid Assessment of Wetland Ecosystem Services approach. Subsequent analysis using the social, technological, environmental, economic, political framework found close, synergistic relationships between local people and the ecosystems for which they have protected tribal rights. Authoritative local governance arrangements prioritise community subsistence needs, limiting the influence of external state government and private actors on natural resource exploitation. Further sustainable economic development could stem from recognition of the value of ecosystem services produced by intact and functional habitats, and the potential for development of 'payment for ecosystem services' markets in addition to ecotourism and cultural tourism. Low food sufficiency and poverty observed in a previous study conducted in Uttarakhand state of the central Indian Middle Himalayas, principal drivers of out-migration and gender/age inequalities, were not evident in Lileng or surrounding areas, apparently linked to tribal rights and authoritative local governance in Arunachal Pradesh leading to greater resource security. Better understanding of ecosystem-community relationships in areas with protected tribal rights can highlight sustainable policies and practices that may be translated into wider geo-political areas, especially in the wake of projected climate change stresses.
\end{abstract}

Keywords Arunachal Pradesh · Community-based management · Livelihoods · North-east Himalayas $\cdot$ PES $\cdot$ India

Electronic supplementary material The online version of this article (https://doi.org/10.1007/s1066 8-020-00945-1) contains supplementary material, which is available to authorized users.

Mark Everard

mark.everard@uwe.ac.uk

Extended author information available on the last page of the article 


\section{Introduction}

Mountains cover 24\% of global land surface (UNEP-WCMC 2002), providing multiple ecosystem services significantly including climate regulation at local and global scales (ICIMOD 2010). They support approximately one-quarter of terrestrial species and almost half of the world's 34 biodiversity 'hot spots' (Körner 2009; CBD 2010, 2011; RSPN 2015). Around $12 \%$ of the global human population inhabits mountains (Huddleston et al. 2003), exhibiting a high diversity of cultures, traditions, resource use and stewardship practices, and significant ecosystem-human interdependencies owing to the inaccessibility and heterogeneity of mountain systems. However, the generally low productivity and their remoteness from markets means that poverty levels are higher in mountain environments than other global habitat types (Körner et al. 2005; Sharma et al. 2010; RSPN 2015).

Everard et al. (2019a) have previously provided an overview of the characteristics of livelihood-ecosystem interdependencies in two contrasting Indian mountain villages in the Middle Himalayan state of Uttarakhand, India. Consistent with India's long practice of decentralised rural governance, Van Panchayats (Forest Councils) established under the Indian Forest Act 1927 operate in Uttarakhand as local-scale participatory management institutions. Van Panchayats have resource use authority within Civil Forests (forest areas owned by State Government but located within village boundaries) within prescribed government limitations, though not in government-owned and managed State Forests, this 'bottom-up' decision-making structure nested within statutory natural resource governance arrangements (Mukherjee 2003). The two case studies presented by Everard et al. (2019a) demonstrated that despite their high biological and cultural diversity and wealth of ecosystem services, providing benefits over multiple scales, the selected communities in Uttarakhand experience significant poverty with low food local availability, decreasing self-sufficiency and increasing dependency on income and food provision from beyond the mountains. Furthermore, much of the income remitted by migrants back to their mountain villages flowed back out of the Himalayan region to purchase food produced from the Gangetic plain, threatening village economic viability and placing asymmetric pressures on resident female, elderly and young people. The Himalayan landscape could potentially represent an economic asset if institutional development focused on sustainable bioprospecting, ecotourism and payment for ecosystem services (PES) schemes for water supply and climate regulation services. However, the current situation is one of socio-economic decline as people fail to support their livelihoods from the diverse mountain ecosystems they inhabit.

By contrast, the contemporary eight north-eastern Indian states-Arunachal Pradesh, Assam, Manipur, Meghalaya, Mizoram, Nagaland, Sikkim and Tripura-are organised under different and far more decentralised governance arrangements. Significant amongst the principal distinctions in governance is the Bengal Eastern Frontier Regulation, 1873 (Regulation 5 of 1873) instituted under British colonial rule as "A Regulation for the peace and Government of certain districts on the Eastern Frontier of Bengal". The Regulation prohibits entry into this zone without a pass issued by the chief executive officer of each district, and does not permit removal of jungle products amongst a range of other restrictions (latestlaws.com 2019). The state of Arunachal Pradesh has additional restrictions for foreigners, who require a Protected Area Permit (PAP), and for Indian tourists who require an Inner Line Permit (ILP), both permits available from Government of Arunachal Pradesh offices. In addition, it is illegal for land to be 
transferred and owned by anyone other than from local tribes. These arrangements grant substantial autonomy to local institutions, protecting tribal rights and authority, diversity, natural resource governance and culture.

Physical geographical conditions in the Middle Himalayan regions of Uttarakhand and Arunachal Pradesh are broadly similar. However, governance arrangements, particularly the authority of local tribes with respect to stewardship of natural resources, are markedly different. This study addresses how ecosystem-human interdependencies manifest in a case study village in Arunachal Pradesh, and how this contrasts with the prior study of the two case study villages in Uttarakhand. Making no assumptions that the selected case study village Lileng is representative of all villages in Arunachal Pradesh, we investigate the outcomes of contrasting governance arrangements for livelihood security and sustainable human-ecosystem interactions.

\section{Methods}

The focus of this study was the specific Arunachal Pradesh village of Lileng (alternatively spelled Leleng), described below. Primary data-gathering comprised semi-structured interviews with tribal leaders and members in the village, all of them of the Adi tribe, as well as with other Arunachal Pradesh natives with business (ecotourism and cultural tourism) involvement in close collaboration with the tribe. Interviews were supported by direct observations during field visits and by literature review.

\subsection{Lileng: the case study village}

Arunachal Pradesh is a tribal state, inhabited by 26 major tribes and 105 sub-tribes with unique socio-cultural identities (Solanki and Chutia 2004). Lileng village (28 $19^{\prime} 25.9^{\prime \prime} \mathrm{N}$ $94^{\circ} 58^{\prime} 01.8^{\prime \prime}$ E) was selected for this study for a number of reasons. Despite the high tribal diversity across the region, Lileng was judged representative by local authors and the opinions of interviewed Lileng residents. It is also the exclusive reserve of one tribe (the Adi) and run by a Village Council. Members of the research team had strong links with representatives of the Village Council.

Lileng village centre and adjacent rivers are accessible by road. In addition, some research team members can converse in the local language (Adi, a dialect of Hindi named after the tribe), though some informants also spoke English. Research team members were also familiar with and sensitive to local customs. Lileng is geographically defined by its location in a jungle valley immediately to the north of the sangam (confluence) of the spring-fed Semang river with the glacial-fed Siang river, recent zonation having been imposed by the Village Council with regard to allocation of fishing rights on the river. The Siang river rises as the Yarlung Tsangpo River from the Angsi Glacier in Tibet. The river is known as the Siang throughout much of Arunachal Pradesh, but also as the Dihang River where it meets the plains downstream. The Siang is the main headwater of the Brahmaputra River, the main stem of which runs for a distance of nearly $2900 \mathrm{~km}$ from its source to discharge into the Bay of Bengal. The Semang River rises in steep mountainous rainforest to the west of Lileng, formed from the merger of three spring-fed rivers: the Libung; the Mabung and the Semang. The Semang joins the Siang River at a sangam (confluence) located between Lileng village to the north and Boleng township to the south. The Semang 
River and surrounding rain forest constitutes a rich source of natural resources, sustaining the wellbeing of the Lileng community.

The 2011 Government of India census records 41 families residing in Lileng, comprising a total population of 231 of which 144 were males and 87 are females, with 25 children aged 0-6, and a literacy rate of $66.02 \%$ (Census of India 2011). The exact village boundary extends into the surrounding, unoccupied dense rainforest-covered mountains and is not defined on a statutory basis (Fig. 1), the border with adjacent villages somewhat fluid and largely agreed by consensus with adjacent villages. Politically, Lileng lies in Silong Block (Development Block under India's devolved central governance system), in the Boleng Circle of East Siang district. The headman (Goan Buddha, or 'old man') and other members of the Village Council are recognised and registered with the state. Though its members receive a small remuneration for their services from the state, in accordance with protected tribal rights legislation, the Village Council has a high degree of autonomy in decisionmaking concerning natural resource use, discipline and a range of local matters. For example, the Village Council decided in 2018 to restrict recreational angling at the sangam (Fig. 2) and a section of the Semang river upstream for visiting angling tourists only, in order to safeguard this valuable ecotourism resource particularly for highly prized mahseer (cyprinid fishes of the genus Tor) and goonch (the catfish Bagarius bagarius). Local anglers from Lileng village are permitted to fish in the Sebang River above the restricted zone, any local angler found fishing in the restricted zone fined INR 50,000 (approximately USD 720) by the Village Council.

A Gram Panchayat (grassroots-level governance structure under India's Panchayati Raj system interfacing with the state government) covers three villages, a higher-level Zila (District) Panchayat interfacing at district level to petition for funds for infrastructure development (drainage schemes, etc.). However, the Village Council resists any significant natural resource influence from the Gram Panchayat to prevent state control of these

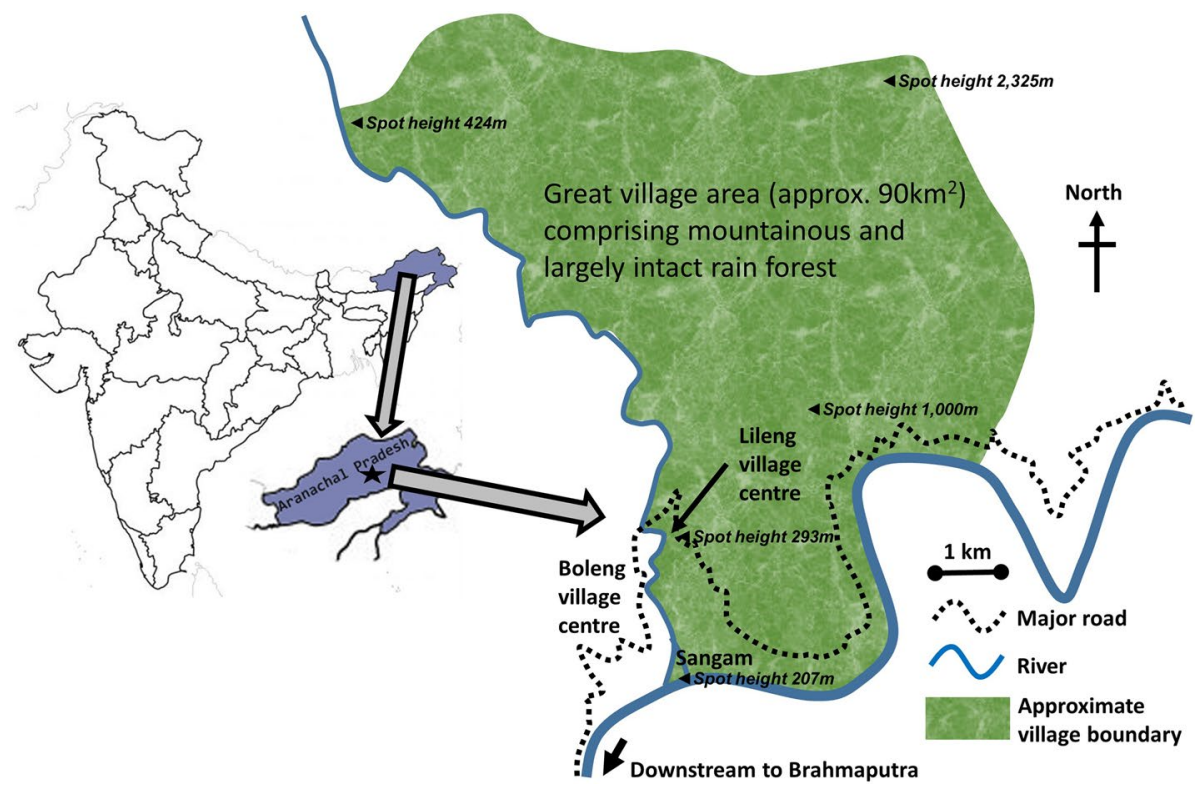

Fig. 1 Location map of Lileng village 


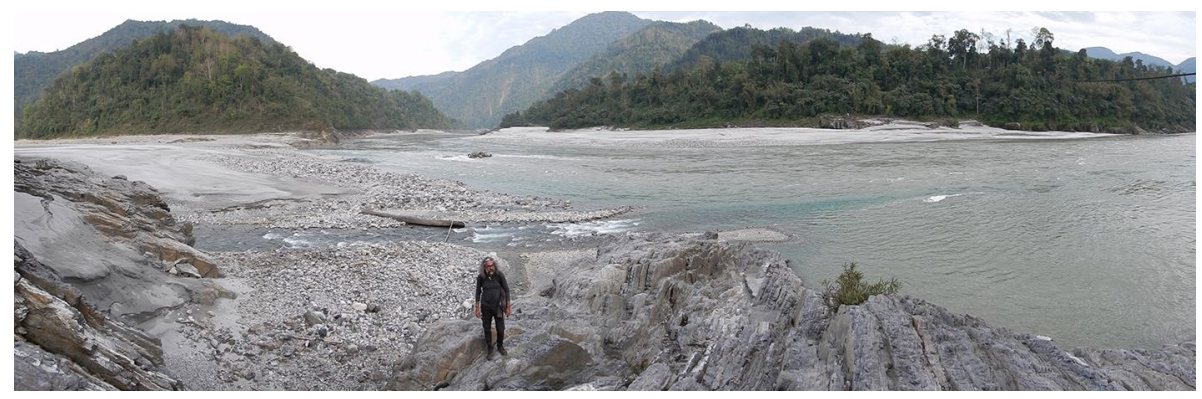

Fig. 2 The sangam (confluence) of the Sebang River with the Siang within the deeply gorged, rainforest landscape is a defining feature of Lileng village (image (c) Mark Everard)

tribally owned and highly valued assets. In addition to local language (Adi), dialects, architecture and customs, villagers are mainly adherents to a native animist religion (Dongibolo, or 'sun moon') leaving offerings to the gods in the forest.

\subsection{Evidence-gathering at Lileng}

Evidence-gathering at Lileng took the form of semi-structured interviews with a number of informants $(N=15)$. Selection of interviewees from Lileng village, all adults comprising 8 men and 4 women all from the Adi tribe, was primarily based on their involvement in village governance (including the former headman), as well as knowledge about other attributes of the village such as the management of angling tourism arrangements and also roles as a teacher, as tribal elders and also the President of the Youth Committee of the Adi tribe. Three additional interviewees, all male of adult age, were selected from a neighbouring tribe in Arunachal Pradesh with close ecotourism and cultural tourism links to Lileng. Discussions took place primarily in Adi, and a minority in English. It is accepted that interviewee sample size is small, though so too is the village (41 families recorded in the 2011 census) and selection of interviewees based on involvement with village governance and resource use activities gives the results legitimacy. Gender sensitivity was also considered, female interviewees were interviewed by a female member of the research team, though no inhibition was encountered in wider discussions with female or other informants. Conversation flowed freely with no evidence of it being dominated by any individuals. Researchers fluent in local languages translated feedback enabling written notes to be collated in English. Names of interviewees were recorded but are omitted from this paper to protect privacy.

The semi-structured interviews were based on two conceptual frameworks: the ecosystem service classification of the Millennium Ecosystem Assessment (as updated in the RAWES approach described below); and the STEEP (social, technological, environmental, economic, political) framework. These conceptual frameworks underpinned prompting questions and recording of responses, though questions were introduced by conversation in locally relevant terms and in a semi-structured way rather than through a rigid questionnaire, reflecting the cultural differences between researchers and local people and the diversity of views of the interviewee group (following Everard et al. 2019a, b). This enabled interviewees to respond freely rather than asking them rigorously to stick to precise questions. All feedback, captured as written notes at the time of interview, was transferred into spreadsheet format, and 
responses were anonymised so that respondents felt free to express their views. Interviewees were asked prior to interview for their consent for feedback to be recorded and used in a nonattributable way for research purposes. Interviewees were also offered the right to withdraw from the process at any time, with contact details for one or more researchers provided at the time of interviews, though no requests to withdraw were received.

Additional input was derived from literature searches (see citations throughout this paper). As studies of societal benefits from ecosystems have not, to date, been necessarily expressed as ecosystem services, particularly so for under-researched Himalayan regions, it was not possible to conduct a fully structured literature review. Instead, searches were based on a range of service-related terms such as fresh water, flood regulation, food security, angling tourism and habitat for wildlife.

\subsection{Analysis of ecosystem service provision and use in the Lileng ecosystem}

Based on evidence from interviews, literature and direct observations, assessment of the ecosystem services accruing to the local community and wider constituencies from the ecosystems of Lileng was undertaken using the Rapid Assessment of Wetland Ecosystem Services (RAWES) approach (Ramsar Convention 2018). RAWES was developed to support ecosystem service assessment of wetlands recognising practical time and resource limitations faced by operational staff, providing a simple, user-friendly, cost-effective approach supporting systemic assessment of the full range of wetland ecosystem services (McInnes and Everard 2017). Although RAWES specifically was developed for wetland assessment, it is in essence adapted from a wider approach already used extensively in a range of habitat types (for example, by Everard 2009; Everard and Waters 2013). RAWES makes a semi-quantitative judgement of the significance of each ecosystem service, as well as the geographical range over which the benefit is realised.

A systemic approach is important for expressing the condition of a wetland in a manner that informs ecosystem-based management (Stein et al. 2009). Genuinely rapid assessment is a key operational need for wetland assessment (Fennessy et al. 2007; Kotze et al. 2012), a guiding principle of RAWES being that no more than two appropriately trained people should spend no more than half a day in the field and another half-day of preparation and analysis. RAWES addresses the four ecosystem service categories (provisioning, regulating, cultural and supporting) defined by the Millennium Ecosystem Assessment (2005), summarised in Table 1. Supporting services are redefined as functions in some subsequent reclassifications (for example, TEEB 2010; Braat and de Groot 2012) to avoid 'doublecounting' benefits. However, supporting services were explicitly retained in RAWES recognising the necessity of integrating their vital underpinning roles in decision-making contexts in order to avert undermining the functioning and resilience of ecosystems, including their capacities to generate other services. RAWES can also be used across a range of scales from whole landscapes to localised zones of large and complex ecosystems.

The semi-quantitative importance of each service was scored on a scale from 'significantly positive' (++) through 'neutral' (0) to 'significantly negative' (--) or 'unknown' (?) as outlined in Table 2. Data captured in handwritten RAWES field assessment sheets were transposed into spreadsheet format, with some modification in dialogue amongst assessors and other experts where more information became available. (A spreadsheet summarising RAWES assessments and supporting evidence is submitted as Supplementary Material A.) To express and compare production of the four ecosystem service categories at Lileng, assigned importance scores were numerically transformed as outlined in Table 2. 
Table 1 Millennium Ecosystem Assessment (2005) ecosystem service categories

\begin{tabular}{ll}
\hline $\begin{array}{l}\text { Millennium ecosystem } \\
\text { assessment ecosystem service } \\
\text { category }\end{array}$ & Summary description \\
\hline Provisioning & $\begin{array}{r}\text { Physical and other resources extracted from ecosystems to support a } \\
\text { diversity of human needs, such as food, fibre and natural medicines }\end{array}$ \\
Regulating & $\begin{array}{l}\text { Regulatory processes within ecosystems maintaining balance, such as } \\
\text { pollination, water purification and climate moderation }\end{array}$ \\
Cultural & $\begin{array}{c}\text { Aspects of ecosystems providing non-material benefits enriching society, } \\
\text { such as those supporting tourism, recreation and spiritual interests }\end{array}$ \\
Pupporting & $\begin{array}{c}\text { Processes within ecosystems that maintain overall functioning and resil- } \\
\text { ience, such as soil formation, photosynthetic production of oxygen and } \\
\text { habitat for wildlife }\end{array}$ \\
\hline
\end{tabular}

Ecosystem services are defined by the Millennium Ecosystem Assessment (2005) as “...the benefits people obtain from ecosystems",

Table 2 Transposition of RAWES 'importance of service' scores into numeric values for analysis and representation

\begin{tabular}{lllllll}
\hline Assigned importance & $\begin{array}{l}\text { Sig- } \\
\text { nificantly } \\
\text { positive }\end{array}$ & Positive & Neutral & Negative & $\begin{array}{l}\text { Sig- } \\
\text { nificantly } \\
\text { negative }\end{array}$ & Unknown \\
\hline Importance score & ++ & + & $\mathbf{O}$ & -- & - & $?$ \\
Numerical value & 1.0 & 0.5 & 0.0 & -0.5 & -1.0 & Remove from analysis \\
\hline
\end{tabular}

Groups of ecosystem services (within Millennium Assessment categories but also across all four categories) were summed and divided by the number of relevant services in that category to derive an ecosystem services index (ESI), based on similar index methods by Butchart et al. (2010) and Davidson et al. (2019). ESIs are calculated using Eq. 1, where ' $n$ TOTAL' was adjusted to remove generic services that were not relevant in this specific context (e.g. waste disposal or fire regulation at Lileng). The potential ESI range is from +1 to -1 , calculated for each of the four ecosystem service categories or a compound value for all services.

$$
\mathrm{ESI}=\frac{\sum\left(n_{+1.0}+n_{+0.5}\right)+\sum\left(n_{-1.0}+n_{-0.5}\right)}{\sum n_{\mathrm{TOTAL}}}
$$

The same mathematical transformation was used to calculate ESIs for total ecosystem service benefits accruing across the four geographical ranges in the RAWES field assessment sheet (local, catchment, national, global) for the 30 relevant services. Total ESIs for geographical scales can exceed 1.0 where benefits accrue across multiple scales.

\subsection{Contextualising ecosystem service benefits within governance arrangements}

Livelihood-ecosystem interdependencies occur within complex socio-ecological systems, the environmental and social elements framed by governance arrangements, technology 
choice and deployment, and economic considerations. The STEEP (Social, Technological, Environmental, Economic, Social) framework was used to address systemic interdependencies between these factors. STEEP was adapted from a range of allied classification schemes by Morrison and Wilson (1996), primarily for analysis of an organisation's operating environment and preparing for organisational transitions (Schmieder-Ramirez and Mallette 2007). The framework has since been applied to analyse interconnections between domains of human activity with regard to meeting the goals of sustainability (Steward and Kuska 2011), including as a systems framework addressing systemic interdependences between constituent elements to evaluate water systems (Everard et al. 2012; Everard 2013, 2015).

\section{Results}

\subsection{Ecosystem service-livelihood interdependencies at Lileng}

The principal results of the RAWES assessment are recorded in the spreadsheet submitted as Supplementary Material A. In all, 30 of 36 ecosystem services in the RAWES assessment sheet were found to be relevant in Lileng: 7 out of 9 provisioning services; 11 out of 14 regulating services; 6 out of 7 cultural services; and all 6 supporting services. Table 3 lists services relevant at Lileng along with ESI scores by ecosystem service category (including all services combined), as well as for the four geographical scales of service benefit realisation (including all ranges combined).

These results demonstrate a very high interdependence of local people with supporting ecosystems, sustainable uses reflecting mutual interactions between natural resources and their beneficiaries. (For comparison, Everard et al. 2019a, b found combined services ESIs of 0.52 and 0.58 , respectively, in the populated Gosaba Island and the protected Sudhanyakhali Island in Sundarbans of West Bengal.) An example of the close dependence on local provisioning services includes houses in Lileng village constructed predominantly from local materials (bamboo frames, walls, ties, wood fuel, steps and many other features, and palm leaf for roofing sealed through tar build-up from bamboo-fuelled fires constantly burning in the centre of each house) (Fig. 3). Shaping of village structure based on local resources is an example of close association with cultural services, which also include recent zonation of fishing rights on the river as a basis for carefully managed angling tourism benefit. Exploitation of adjacent forests within renewable limits illustrates traditional stewardship practices framed around conserving supporting services, and limited rotational tillage averting excessive erosion illustrates synergy with regulating services.

Benefit realisation from the Lileng ecosystem is overwhelmingly local $(\mathrm{ESI}=0.87)$, including 6 of the 7 relevant provisioning services (fresh water, food, fibre/fuel, natural medicines, ornamental resources, and clay/minerals), 9 of the 11 relevant regulating services (regulation of local climate, water flows, natural hazard, pests, erosion, and human and livestock diseases, and water/waste and pollination) and all relevant cultural and supporting services, although to a lesser degree, contributions of services to the wider Brahmaputra catchment are significant $(\mathrm{ESI}=0.37$ ), including 3 provisioning services (fresh water, fibre/fuel and clay/minerals), 3 regulating services (water flows, erosion regulation and water/waste purification), 2 cultural services (recreation/tourism and education/ research) and 3 supporting services (primary production, water recycling and provision of habitat). The Lileng ecosystem also produces a range of potential services (genetic 
Table 3 ESI scores for each ecosystem service category and all services combined (left columns), and ESI scores for each geographic range of benefit realisation and all ranges combined (right columns)

ESI by ecosystem service category

Services observed as relevant at Lileng
ESI by geographical scale of benefit delivery

$0.86 \quad$ Local

0.87

Provisioning

Fresh water

Food production

Fibre and fuel production

Genetic resources

Biochemicals, natural medicines, pharmaceuticals

Ornamental resources

Harvesting of clay, mineral, aggregates, etc.

Regulating

Catchment

Air quality regulation

Local climate regulation

Global climate regulation

Water regulation (hydrological)

Natural hazard regulation

Pest regulation

Disease regulation-human

Disease regulation-stock

Erosion regulation

Water purification and waste treatment

Pollination

Cultural

National

Cultural heritage

Recreation and tourism

Spiritual and religious value

Inspiration of art, folklore, architecture, etc.

Social relations

Educational and research

Supporting

Soil formation

Primary production

Nutrient cycling

Water recycling

Photosynthesis (production of atmospheric oxygen)

Provision of habitat

Combined services

0.85

Combined scales

1.50

resources, energy harvesting, air quality regulation, photosynthetic oxygen production, opportunities for waste disposal, and noise and visual buffering) that are either not limited in the locality or else not exploited, and so cannot be defined as services as they are not currently linked to a clear beneficiary.

\subsection{Systemic interdependencies in the Lileng socio-ecological system}

Ecosystem-human interdependencies happen within complex socio-ecological systems, with highly interdependent governance arrangements, technology choice and economic considerations. To explore these interdependencies within the Lileng village socio-ecological system, information gathered was stratified using the STEEP model applied as a systems framework addressing five principal questions (one per STEEP component) each 


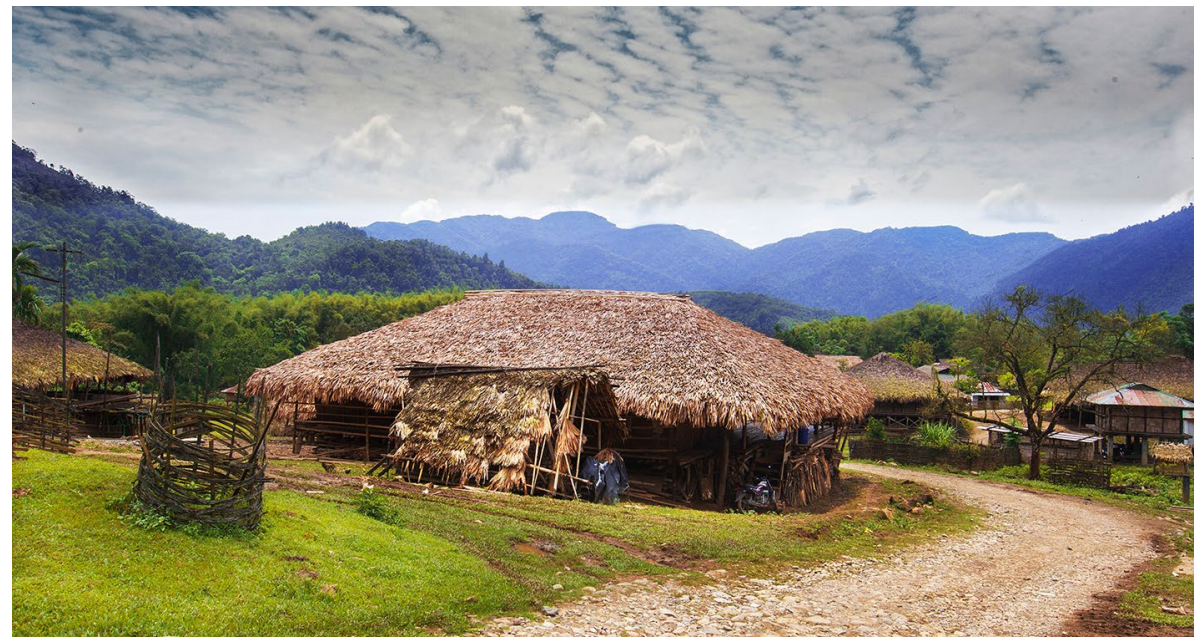

Fig. 3 Housing in Lileng village predominantly constructed, internally and externally, from local forestderived materials (image $(\mathcal{C}$ Mark Everard)

of which was supported by four contextual questions (interrelationships with other STEEP elements) following Everard (2020) and Everard and Quinn (in press). This analysis is presented in tabular form in Supplementary Material B.

In summary, social structure is shaped by tribal rights enshrined in legislation enabling significant autonomy over technology choice, economic activities and sustainable ecosystem uses. Technologies damaging to ecosystem structure and service are opposed, through modern benefits such as medical services and telecommunications are adopted, with subsistence level approaches to cropping, forest and fishery harvesting controlled under village-level governance. Economic activities under village governance arrangements focus substantially upon village self-sufficiency, maintaining the natural resources of rivers and forests as a primary form of capital. Sustainable stewardship of ecosystems and their services is central to local governance arrangements. These governance arrangements are based on participatory approaches protecting tribal rights and prioritising self-sufficiency and sustainable resource use.

Strong coherence is evident across the STEEP system. This differs from many socioecological systems in which market-led, top-down government diktat, industrial or other priorities tend to drive development decisions overriding and eroding the resilience of ecosystems supporting local livelihoods and wellbeing, a widespread global trend that is also observed in north-east India (Ali 2017).

\section{Discussion}

Human-ecosystem connections operate interactively, local people playing important roles in use and management of, as well as impacts on, the ecosystems that support their needs (Folke et al. 2005). Consequently, integrated socio-ecological systems can operate in a degenerative cycle when the vitality and supportive capacities of unsustainably used ecosystems decline, with inevitable adverse outcomes for socio-economic wellbeing (as, for example, seen in global soil loss trends driven by unsound intensive farming practices: 
Borrelli et al. 2017). Alternatively, ecosystem protection or restoration can create regenerative socio-ecological cycles, in which maintenance or enhancement of ecosystem resilience and services offers improved human security and opportunity (for example, in the raising of many people out of poverty consequent from 'regreening' formerly severely eroding sloping lands on China's Loess Plateau: Li et al. 2019). Numerous examples of both degenerative and regenerative socio-ecological cycles are reviewed by Everard (2020).

\subsection{The Lileng socio-ecological system}

In Lileng, there is a close and synergistic relationship between local people and the forest and riverine ecosystems for which they have protected tribal rights. The diverse supportive capacities of these supporting ecosystems are well understood and sensitively used through consensual decision-making framed substantially around village self-sufficiency, representing a regenerative, inherently sustainable socio-ecological cycle. Outcomes of this synergistic relationship with, and high dependence upon, local natural resources are reflected in the overall ESI of 0.85 for all relevant ecosystem services. Benefits by ecosystem service category range from 0.82 for regulating services to 0.92 for cultural services, the latter reflecting how societal structure is framed by surrounding ecosystems. The ESI of 0.86 for provisioning service reflects high material reliance on local supportive ecosystems, the ESI of 0.83 for supporting services indicating maintenance of foundational ecosystems and processes. This synergistic and inherently sustainable relationship between societal needs and the surrounding and supportive ecosystems is embedded in tribal culture, traditions and beliefs, and enabled by authoritative local governance arrangements enshrined in protected tribal rights.

Analysis of the systemic interconnections between the five components of the STEEP framework expands on how societal benefits flowing from the natural environment in the form of ecosystem services are governed and valued within the complex socio-ecological system. There is strong coherence across the STEEP system, unlike many socio-ecological systems in which unsustainable development priorities tend to erode supporting ecosystems and, consequently, dependent livelihoods and wellbeing. Protected tribal rights in Lileng give authority to local communities with regard to natural resource use, leading to low intervention strategies and to technology choices sympathetic with and making traditional uses of supporting ecosystems. This results in a high degree of self-sufficiency, and the use of forest, riverine and other resources for medicinal, construction, water supply and other purposes without excessive dependence on external resources (though there is some trading of food, construction and other commodities). Governance systems are predominantly participatory via Village Councils, which have considerable autonomy relative to state governance arrangements, maintaining as a priority the subsistence needs of the community.

The strong emphasis of local tribal institutions and people on retaining the natural resources of Lileng as a basis for sustainable livelihoods, rejecting government interference and intensive modification of river and other tribally owned resources, is strongly reflected in the substantial ESI of 0.87 for local realisation of ecosystem service benefits. ESI scores of 0.37 for catchment-sale benefits and 0.13 for both national and global benefits indicate wider benefits flowing from Lileng's ecosystems. Strong local institutions enabled by protected tribal arrangements in Arunachal Pradesh have empowered communities to resist state interests in harnessing the flows of the Siang river by dams for hydropower generation (a list of schemes proposed by the state is presented in Table 4). Whilst lucrative for some sectors of society, particularly providing power and water supplies for intensive users, 
Table 4 Government-supported dam project proposals on the Siang River

Government-supported dam project proposals on the Siang River (Arunachal Bhawan, undated) include

- 257 m rockfill/concrete 11000 MW Siang Upper HE Project near Goging village

- 154 m rockfill 700 MW Siang Middle (Siyom) HE Project on Siyom river near Raying village

- 65 m rockfill 1700 MW Siang Lower HE Project near Rotung village

- $265 \mathrm{~m}$ rockfill/concrete 2500 MW Subansiri Upper HE Project

- 213 m rockfill 2000 MW Subansiri Middle (Kamla) HE Project further downstream in Assam state; and

- 116m 2000 MW Subansiri Lower HE Project also in Assam but with most of the submergence area in Arunachal Pradesh

major damming projects substantially disrupt riverine and adjacent ecosystems with multiple direct and indirect impacts on a range of non-focal ecosystem services and associated service beneficiaries (World Commission on Dams 2000; Everard 2013). Major dams on the Siang river could profoundly change the character of the whole river system and valley and the closely adapted tribal structures, livelihood dependencies and traditions. Further examples of tribal decision-making to sustain resources of importance for continuing livelihoods in Lileng include conservation of intact forest to safeguard untreated water resources and as a renewable source of building and medicinal resources, and the protection of fish stocks of value as recreational resources as a basis for sustainable revenue generation from angling tourism (consistent with the success criteria behind PES arrangements for recreational angling noted by Everard and Kataria 2011).

\subsection{Comparison with the socio-ecological system of Uttarakhand villages}

Reanalysis of findings from the case study villages in Uttarakhand by Everard et al. (2019a) suggests ESI values of 0.50 for provisioning, 0.68 for regulating, 0.72 for cultural, 0.75 for supporting and 0.60 for all relevant services combined. These substantially lower ESI scores across all ecosystem service categories, in otherwise geographically comparable Middle Himalayan landscapes, reflect low dependence on exploitation of forest resources by villagers. The figures reported from islands in the Sundarbans in West Bengal by Everard et al. (2019a, b) are lower still, reflecting even lesser direct interaction with ecosystems than in Lileng or the Uttarakhand villages.

The low food sufficiency observed in Uttarakhand (Everard et al. 2019a, b) was a principal driver of the widespread, long-term or permanent out-migration of younger men from Uttarakhand's mid-hills, imposing asymmetrically high pressures on women and the elderly (Mamgain and Reddy 2017). Young men were almost completely absent in the two case study villages in Uttarakhand. By contrast, young men were conspicuous in Lileng and its vicinity, and were active participants in livelihood practices including through engagement in the Youth Committee of the Adi tribe.

Based on the STEEP framework, little coherence was observed across the socio-ecological systems of the case study villages in Uttarakhand. Little use was made of adjacent forest ecosystems for services such as food provision or economic activities, and governance was imposed from state level limiting the effectiveness of Van Panchayat level decision-making and livelihood opportunities. State prohibitions on forest resource exploitation in Uttarakhand were seen as a principal reason for declining agriculture and food security, driving a cycle of village outmigration and various forms of self-sufficiency and 
vulnerability, within a degrading socio-ecological cycle driven not by insufficiency of local ecosystem services but by their effective unavailability.

\subsection{Potential development opportunities in Lileng}

In addition to contributing to the flows of the Siang river system, the natural capital of Lileng village and wider Arunachal Pradesh produces a richness of ecosystem services benefitting stakeholders well beyond the state. There is potential for identifying economic benefit under 'payments for ecosystem services' (PES) or other arrangements if beneficiaries can be linked with ecosystem stewards. As noted, the potential services of genetic resources, energy harvesting (already considered in terms of the hydropower schemes above), air quality regulation, photosynthetic oxygen production, opportunities for waste disposal, and noise and visual buffering are either not limited in the locality or else not utilised by any beneficiaries, and hence currently are not technically defined as services and counted in ESIs.

Other services, such as global climate regulation through carbon storage and sequestration, hydrological buffering, water quality regulation and provision of fresh water downstream could have potential markets. Arunachal Pradesh has high potential for PES-based climate regulation markets under the REDD + mechanism (Ravindranath et al. 2012). Recognising that any form of development has to be sympathetic with tribal rights, traditions and aspirations, it is possible to envisage some forms of beneficial yet sustainable markets founded on these ecosystem services. Ecologically and culturally sensitive development already occurs in Lileng through income from low-impact ecotourism, including both recreational angling and cultural tourism for which management arrangements are already in place, as well as licensing of river valley aggregate extraction and the trading of a minority of locally produced crops. These activities are consistent with the Ramsar Convention principles of 'wise use', retaining 'ecological character' (Finlayson et al. 2011).

Further geographically, environmentally and culturally sensitive economic development could reinforce the significant engagement of the local community in ecosystem and natural resource conservation. Maintaining engagement between people and their supportive ecosystems is essential as local communities play key roles in enduring, effective and equitable nature conservation (Emerton 1999; Larsen and Springer 2008), as evidenced by the close relationship to date of the Adi tribe with the ecosystems that support them and their associated governance and traditional practices.

\subsection{Differing governance arrangements}

The substantial differences observed between the two case study villages in Uttarakhand and Lileng in Arunachal Pradesh appears to be linked to significant differences in state governance arrangements, and particularly the direct ownership and retention of tribal rights and authority in Arunachal Pradesh. Substantial state ownership, control and undermining of authority of the Van Panchayats were observed by Everard et al. (2019a, b) as limiting factors on sustainable interdependence between forest resources and human livelihoods in Uttarakhand villages. The effective removal of higher-level interventions by state actors under the protected tribal rights in Arunachal Pradesh is a significant factor in protecting sustainable relationships between natural capital and low-impact human activities. 


\subsection{Resilience in the face of future threats}

Retaining the structure and resilience of supporting ecosystems has additional importance in the face of projected climate change trends. It is suggested that temperatures across the Hindu Kush Himalayan region may increase by $1-2{ }^{\circ} \mathrm{C}$ by 2050 , compared to a 1960 s baseline; the monsoon season is likely to extend and become more erratic; precipitation is projected to change by $5 \%$ on average; and the intensity of extreme rainfall events is likely to increase (Alfthan et al. 2018). Furthermore, climate models project substantial losses in glacial mass and area in the coming decades for most parts of the region (Alfthan et al. 2018). These projected impacts are likely to present additional risks in the area, for which protection of forests and their ecosystem services may build resilience.

Further threats are technological, economic and demographic. Arunachal Pradesh is experiencing growing developed world media exposure and other influences, particularly affecting the attitudes and aspirations of younger people (as directly evidenced by their common adoption of western clothing). Maintaining the central importance of sustainable relationships with and conservation of supporting ecosystems is important for the future wellbeing of village communities. Clear articulation of the many benefits provided by these ecosystems, and ideally some degree of sympathetic development based on their services, may be important for engaging and informing younger generations. Both the Ramsar Convention (2014) and the Convention on Biological Diversity (CBD 2017) place significant emphasis on targeting youth in CEPA (Communication, Education and Public Awareness) programmes as a necessary foundation for ongoing societal support for biodiversity, ecosystem and natural resource conservation.

\subsection{Limitations of this study}

We acknowledge significant limitations and uncertainties inherent in focusing efforts on just one village, particularly given the high tribal diversity across the region. This was enforced by resource limitations, field visits and interviews in particular taking substantial patience and time. We do not assume that findings at Lileng are representative of all or even most villages in Arunachal Pradesh. However, other features of Lileng noted in the Methods section - inhabitation by a single tribe; strong links with the Village Council; accessibility by road; abilities in local dialect and language; sensitivity to local customs; geographically defined by the jungle river valley location; and recent reallocation of fishing rights on the river-mean that it was a suitable case study site, with all of these features not readily available elsewhere.

Although the findings of this study are therefore subject to largely unquantifiable uncertainty, they are nonetheless significant in illustrating how different governance arrangements have profound impacts on whole socio-ecological systems and the extent of sustainable accommodation between people and natural capital.

\subsection{Further research needs}

Further research needs include deeper understanding of sustainable ecosystem-community relationships in regions with protected or otherwise strong tribal rights. Ideally, this should include work in more villages in north-eastern India, with the aim of deriving common principles that may be transferrable to sustainable natural resource governance across wider geopolitical regions. Determination of the relevance and application of these 
principles beyond tribally protected regions would add further value to sustainable and pro-conservation policies and practices, aided by knowledge transfer at the science-policy interface.

Improved knowledge about key factors behind sustainable use of natural resources contributing to regenerative socio-ecological cycles could also be useful in challenging prevalent, simplistic presumptions in favour of narrowly framed economic development (intensive land conversion, timber extraction, river damming, mining, industrial encroachments, etc.) that are often unconsciously or wilfully blind to their wider and distributional socioecological ramifications (Kanbur et al. 2013). Influencing a change in global resource use habits from those that undermine the ecological roots of continuing human wellbeing (Millennium Ecosystem Assessment 2005; Brondizio et al. 2019) towards sustainable and regenerative socio-ecological systems founded on wisely used or restored ecosystem functioning (Everard 2020) is a pressing global challenge broadly consistent with the intent of the 2021-2030 UN Decade on Ecosystem Restoration (UN 2019). These transformational challenges may be usefully informed by learning from governance principles embedded in tribally controlled regions.

\section{Conclusions}

- Intactness of forest and river ecosystems surrounding Lileng village, observed and indicated by ecosystem service analysis and ESI scores, demonstrates a sustainable relationship between tribal people and ecosystems supporting their wellbeing.

- This sustainable accommodation is significantly enabled by authoritative local governance practices enshrined in protected tribal arrangements, limiting the influence of external state and private actors on natural resources owned and sustainably exploited by the Adi tribe.

- Resistance to intensive interventions such as damming schemes on the Siang river, in favour of sustainable levels of exploitation (extraction of local construction materials, protection of the river fishery, etc.), retains the ecological character of the region consistent with the Ramsar Commission's definition of 'wise use'.

- Further economic development could stem from recognition of the value of sustainable use of ecosystem services produced by the intact and functional habitats of Arunachal Pradesh, potentially through 'payment for ecosystem services' (PES) arrangements with beneficiaries outside the immediate region.

- The low food sufficiency and poverty observed in villages in Uttarakhand, a principal driver of out-migration and gender/age inequalities, was not evident in Lileng or surrounding areas apparently due to tribal ownership and governance arrangements in north east India prioritising village self-sufficiency.

- Further research is required to deepen understanding of sustainable ecosystem-community relationships in areas with protected tribal rights, and their relevance for and translation into wider geo-political areas as a foundation for sustainable forms of development protective of supportive ecosystems.

Acknowledgements The author is grateful for co-funding from the International Water Security Network, which is funded by Lloyd's Register Foundation, a charitable foundation helping to protect life and property by supporting engineering-related education, public engagement and the application of research. Additional funding for travel by the senior author was provided by the University of the West of England. 
Open Access This article is licensed under a Creative Commons Attribution 4.0 International License, which permits use, sharing, adaptation, distribution and reproduction in any medium or format, as long as you give appropriate credit to the original author(s) and the source, provide a link to the Creative Commons licence, and indicate if changes were made. The images or other third party material in this article are included in the article's Creative Commons licence, unless indicated otherwise in a credit line to the material. If material is not included in the article's Creative Commons licence and your intended use is not permitted by statutory regulation or exceeds the permitted use, you will need to obtain permission directly from the copyright holder. To view a copy of this licence, visit http://creativecommons.org/licenses/by/4.0/.

\section{References}

Alfthan, B., Gupta, N., Gjerdi, H.L., Schoolmeester, T., Andresen, M., Jurek, M., et al. (2018) Outlook on climate change adaptation in the Hindu Kush Himalaya. Mountain adaptation outlook series. United Nations Environment Programme, GRID-Arendal and the International Centre for Integrated Mountain Development, Vienna, Arendal and Kathmandu. www.unep.org, www.grida.no, www.icimod.org

Ali, N. (Ed.). (2017). Natural resource management and sustainable development in north-east India. New Delhi: Mittal Publications.

Arunachal Bhawan (undated) Hydro power projects in Arunachal Pradesh. Arunachal Bhawan. (http://www. arunachalbhawan.com/hydro.htm, accessed April 26, 2019.)

Borrelli, P., Robinson, D. A., Fleischer, L. R., et al. (2017). An assessment of the global impact of 21st century land use change on soil erosion. Nature Communications, 8, 2013. https://doi.org/10.1038/s4146 7-017-02142-7.

Braat, L. C., \& de Groot, R. (2012). The ecosystem services agenda: Bridging the worlds of natural science and economics, conservation and development, and public and private policy. Ecosystem Services, 1, 4-15. https://doi.org/10.1016/j.ecoser.2012.07.011.

Brondizio, E. S., Settele, J., Díaz, S., \& Ngo, H. T. (2019). Global assessment on biodiversity and ecosystem services of the intergovernmental science-policy platform on biodiversity and ecosystem services (IPBES). IPBES. https://www.ipbes.net/global-assessment-biodiversity-ecosystem-services. Accessed May 12, 2020

Butchart, S. H. M., Walpole, M., Collen, B., et al. (2010). Global biodiversity: Indicators of recent declines. Science, 328, 1164-1168.

CBD. (2010). COP 10 decision X/30 mountain biological diversity. Montreal: Convention on Biological Diversity Secretariat. http://www.cbd.int/decision/cop/?id=12296. Accessed May 12, 2020

CBD. (2011). Programme of Work on mountain biological diversity. Montreal: Convention on Biological Diversity Secretariat. http://www.cbd.int/mountain/pow.shtml. Accessed May 12, 2020

CBD. (2017). Aichi Biodiversity Target 1 and CEPA. Montreal: Convention on Biological Diversity Secretariat. https://www.cbd.int/cepa

Census of India. (2011). Lileng Population - East Siang, Arunachal Pradesh. Census 2011 (India). (http:// www.census2011.co.in/data/village/263778-lileng-arunachal-pradesh.html, accessed May 12, 2020.)

Davidson, N. C., Dinesen, L., Fennessey, S., Finlayson, C. M., Grillas, P., Grobicki, A., et al. (2019). Wetland ecological status and changes: A meta-analysis. Marine and Freshwater Research, 71(1), 127138. https://doi.org/10.1071/MF18329.

Emerton, L. (1999). Community-based incentives for nature conservation. IUCN-The World Conservation Union, Eastern Africa Office. https://testportals.iucn.org/library/sites/library/files/documents/PDF2000-001.pdf. Accessed May, 122020.

Everard, M. (2009). Ecosystem services case studies. Environment Agency Science report SCHO0409BPVM-E-E. Bristol: Environment Agency. https://www.gov.uk/government/uploads/system/uploads/ attachment_data/file/291631/scho0409bpvm-e-e.pdf.

Everard, M. (2013). The hydropolitics of dams: Engineering or ecosystems?. London: Zed Books.

Everard, M. (2015). Community-based groundwater and ecosystem restoration in semi-arid north Rajasthan (1): Socio-economic progress and lessons for groundwater-dependent areas. Ecosystem Services, 16, 125-135. https://doi.org/10.1016/j.ecoser.2015.10.011.

Everard, M., Harrington, R., \& McInnes, R. J. (2012). Facilitating implementation of landscape-scale integrated water management: The integrated constructed wetland concept. Ecosystem Services, 2, 27-37.

Everard, M., Gupta, N., Scott, C. A., Tiwari, P. C., Joshi, B., Kataria, G., et al. (2019a). Assessing livelihood-ecosystem interdependencies and natural resource governance in Indian villages in the 
Middle Himalayas. Regional Environmental Change, 19(1), 165-177. https://doi.org/10.1007/s1011 3-018-1391-x.

Everard, M., Kangabam, R., Tiwari, M. K., McInnes, R. J., Kumar, R., Talukdar, G. H., et al. (2019b). Ecosystem service assessment of selected wetlands of Kolkata and the Indian Gangetic Delta: Multibeneficial systems under differentiated management stress. Wetlands Ecology and Management. https ://doi.org/10.1007/s11273-019-09668-1.

Everard, M. (2020). Rebuilding the Earth: Regenerating our planet's life support systems for a sustainable future. London: Palgrave Macmillan.

Everard, M., \& Kataria, G. (2011). Recreational angling markets to advance the conservation of a reach of the Western Ramganga River. Aquatic Conservation, 21(1), 101-108. https://doi.org/10.1002/ aqc. 1159 .

Everard, M., \& Quinn, N. W. (in press). Landscapes that hold water: Contrasting perspectives and opportunities from perceived dry (Rajasthan) and wet (England) climatic zones (in press)

Everard, M., \& Waters, R. D. (2013) Ecosystem services assessment: How to do one in practice. London: Institution of Environmental Sciences. https://www.the-ies.org/sites/default/files/reports/ecosy stem_services.pdf.

Fennessy, M. S., Jacobs, A. D., \& Kentula, M. E. (2007). An evaluation of rapid methods for assessing the ecological condition of wetlands. Wetlands, 27(3), 543-560.

Finlayson, C. M., Davidson, N., Pritchard, D., Milton, G. R., \& Mackay, H. (2011). The Ramsar convention and ecosystem-based approaches to the wise use and sustainable development of wetlands. Journal of International Wildlife Law and Policy, 14, 176-198.

Folke, C., Fabricius, C., Cundill, G., Schultz, L., Queiroz, C., Gokhale, Y., et al. (2005). Chapter 11: Communities, ecosystems, and livelihoods. In D. Capistrano, C. Samper, M. J. Lee, \& C. Raudsepp-Hearne (Eds.), Ecosystems and human well-being: Findings of the sub-global assessments working group vol 4: Multiscale Assessments (Millennium Ecosystem Assessment). Washington DC: Island Press.

Huddleston, B., Ataman, E., \& d'Ostiani, L. (2003). Towards a GIS-based analysis of mountain environments and populations. Environment and Natural Resources Working Paper No. 10. Rome: Food and Agriculture Organization of the United Nations.

ICIMOD. (2010). Mountains of the world: Ecosystem services in a time of global and climate change: Seizing opportunities-meeting challenges. Framework paper prepared for the Mountain Initiative of the Government of Nepal by ICIMOD and the Government of Nepal, Ministry of Environment.

Kanbur, R., Rhee, C., \& Zhuang, J. (Eds.). (2013). Inequality in Asia and the Pacific: Trends, drivers, and policy implications. London: Routledge.

Körner, C. (2009). Conservation of mountain biodiversity in the context of climate change. In Proceedings of the international mountain biodiversity conference, Kathmandu, November 16-18, 2008, ICIMOD, Kathmandu, Nepal.

Körner, K., Ohsawa, M., Spehn, E., Berge, E., Bugmann, H., Groombridge, B., et al. (2005). Chapter 24: Mountain Systems. In R. Hassan, R. Scholes, \& N. Ash (Eds.), Ecosystems and human wellbeing. Current state and trends: Findings of the condition and trends working group. Millennium ecosystem assessment (Vol. 1, pp. 681-716). Washington: Island Press.

Kotze, D. C., Ellery, W. N., Macfarlane, D. M., \& Jewitt, G. P. W. (2012). A rapid assessment method for coupling anthropogenic stressors and wetland ecological condition. Ecological Indicators, 13(1), 284-293.

Larsen, P. B., \& Springer, J. (2008). Mainstreaming WWF principles on indigenous peoples and conservation in project and programme management. Gland: World Wide Fund for Nature (WWF).

latestlaws.com. (2019). Bengal Eastern Frontier Regulation, 1873. https://www.latestlaws.com/bareacts/state-acts-rules/west-bengal-state-laws/bengal-eastern-frontier-regulation-1873/. Accessed May 12, 2020.

Li, Y., Mao, D., Feng, A., \& Schillerberg, T. (2019). Will human-induced vegetation regreening continually decrease runoff in the loess plateau of China? Forests, 10(10), 906. https://doi.org/10.3390/f10100906.

Mamgain, R. P., \& Reddy, D. N. (2017). Out-migration from the hill region of Uttarakhand: Magnitude, challenges, and policy options. In D. Reddy \& K. Sarap (Eds.), Rural labour mobility in times of structural transformation (pp. 209-235). Singapore: Palgrave Macmillan.

McInnes, R. J., \& Everard, M. (2017). Rapid assessment of wetland ecosystem services (RAWES): An example from Colombo, Sri Lanka. Ecosystem Services, 25, 89-105.

Millennium Ecosystem Assessment. (2005). Ecosystems and human well-being: synthesis. Washington DC: Island Press. 
Mishra, A., Agrawal, N. K., Thorup, G., Bisht, S., Leikanger, I. C. P., \& Gupta, N. (2017). Strengthening women's roles as risk and resource managers at the frontline of climate change. In: Butler, C. (Ed.) International Centre for Integrated Mountain Development (ICIMOD), Kathmandu, Nepal.

Morrison, J., \& Wilson, I. (1996). The strategic management response to the challenge of global change. In H. Didsbury (Ed.), Future vision, ideas, insights, and strategies. Bethesda: The World Future Society.

Mukherjee, P. (2003). Community forest management in India: The Van Panchayats of Uttranchal. Paper submitted to the XII world forestry congress, 2003, Quebec City, Canada. FAO, Rome http://www. fao.org/docrep/ARTICLE/WFC/XII/0108-C1.HTM. Accessed May 12, 2020

Ramsar Convention. (2014). The CEPA programme. Ramsar convention on Wetlands. https://www. ramsar.org/activity/the-cepa-programme.

Ramsar Convention. (2018). Resolution XIII.17: Rapidly assessing wetland ecosystem services. In 13th meeting of the conference of the contracting parties to the Ramsar convention on Wetlands. https:// www.ramsar.org/about/cop13-resolutions

Ravindranath, N. H., Srivastava, N., Murthy, I. K., Malaviya, S., Munsi, M., \& Sharma, N. (2012). Deforestation and forest degradation in India-implications for REDD +. Current Science, 102(8), 1117-1125.

Rerkasem, K., Yimyam, N., Korsamphan, C., Thong-Ngam, C., \& Rerkasem, B. (2002). Agrodiversity lessons in Mountain Land Management. Mountain Research and Development, 22(1), 4-9. https://doi. org/10.1659/0276-4741(2002)022\%5b0004:ALIMLM\%5d2.0.CO;2.

RSPN. (2015). Ecosystem services for sustainable livelihoods: Barshong Tsirang case study, 2015, Policy Brief. Thimphu: Royal Society for Protection of Nature.

Schmieder-Ramirez, J., \& Mallette, L. (2007). The SPELIT power matrix: Untangling the organizational environment with the SPELIT leadership tool. North Charleston: BookSurge.

Scott, C. A., Zhang, F., Mukherji, A., Immerzeel, W., Bharati, L., Mustafa, D., et al. (2018) Water security: Resource availability, use and governance in the Hindu Kush-Himalaya region. Chapter 8, Hindu Kush-Himalaya Monitoring and Assessment. Cambridge: Cambridge University Press.

Sharma, E., Chettri, N., \& Oli, K. P. (2010). Mountain biodiversity conservation and management: A paradigm shift in policies and practices in the Hindu Kush-Himalayas. International Ecological Research, 25, 909-923. https://doi.org/10.1007/s11284-010-0747-6.

Solanki, G. S., \& Chutia, P. (2004). Ethno zoological and socio-cultural aspects of monpas of Arunachal Pradesh. Journal of Human Ecology, 15(4), 251-254. https://doi.org/10.1080/09709274.2004.11905 701.

Stein, E. D., Brinson, M., Rains, M. C., Kleindl, W., \& Hauer, F. R. (2009). Wetland assessment debate: Wetland assessment alphabet soup: How to choose (or not choose) the right assessment method. The Society of Wetland Scientists Bulletin, 26(4), 20-24.

Steward, W. C., \& Kuska, S. (2011). Sustainometrics: Measuring sustainability-design, planning, and public administration for sustainable living (p. 144). Norcross, GA: Greenway Communications.

Taneja J (2016) Examining the nature and level of participation in community-based natural resource management-a case study of Ramgarh micro-hydropower project, Nainital, India. Master of Philosophy thesis, Monash University, Monash South Africa

TEEB. (2010). The economics of ecosystems and biodiversity ecological and economic foundations. Earthscan: London and Washington.

Tse-ring, K., Sharma, E., Chettri, N., \& Shrestha, A. (Eds.) (2010). Climate change vulnerability of mountain ecosystems in the eastern Himalayas. Climate change impact on vulnerability in the eastern Himalayas-Synthesis report. Kathmandu: ICIMOD. http://lib.riskreductionafrica.org/bitstream/handl e/123456789/485/climate\%20change\%20vulnerability\%20of\%20mountain\%20ecosystems\%20in\%20 the\%20Eastern\%20Himalayas.pdf?sequence=1. Accessed April 20, 2018

UN. (2019). Decade on ecosystem restoration. New York: United Nations (UN). https://www.decadeonre storation.org/

UNEP-WCMC. (2002). Mountain watch: Environmental change and sustainable development in mountains. Nairobi: UNEP. https://www.unep-wcmc.org/resources-and-data/mountain-watch-environmentalchange-sustainable-development-in-mountains. Accessed April 20, 2018

World Commission on Dams. (2000). Dams and development: A new framework for better decision-making. London: Earthscan.

Publisher's Note Springer Nature remains neutral with regard to jurisdictional claims in published maps and institutional affiliations. 


\section{Affiliations}

\section{Mark Everard $^{1}$ (D) - Gaurav Kataria ${ }^{2} \cdot$ Smita Kumar ${ }^{2} \cdot$ Nishikant Gupta $^{1}$}

Gaurav Kataria

katgaurav@gmail.com

Smita Kumar

kumarsmita24@gmail.com

Nishikant Gupta

nishikantgupta@live.in

1 Department of Geography and Environmental Management, University of the West of England, Frenchay Campus, Coldharbour Lane, Bristol BS16 1QY, UK

2 AE Travel Pvt. Ltd, \#47, 3rd Floor, Bharat Nagar, New Friends Colony, New Delhi, India 